\title{
Ready for the best
}

\section{The large investments in research and education made in recent years have provided Brazilian scientists with the conditions to achieve scientific excellence.}

Brazil is the largest country in South America, with an area covering more than half of the continent. It has the fifth largest population in the world with close to 193 million inhabitants. It's a land of natural resources and is famous for its art, music and sporting excellence. A recent focus in The Economist describes it as a country with huge potential that has always struggled to deliver ${ }^{1}$. But now the time for achievement seems to have arrived.

During the past 15 years, Brazil's economy has been growing steadily - it was barely affected by the global recession - and there is no sign that this will change any time soon. In this issue we take a closer look at how the economic growth has influenced science in the country.

Many will argue that current president Luiz Inácio Lula da Silva owes most of his political and economical success to his predecessor, Fernando Henrique Cardoso. But even those who were most sceptical at the time of Lula's election have to recognize that his government has made a strong effort to develop science. The Interview with the present Minister for Science and Technology, Sergio Machado Rezende ${ }^{2}$, and the Commentary by Ado Jorio and colleagues at the University of Minas Gerais ${ }^{3}$ provide an overview of the concerted effort to target excellence in both research and education. Funding has increased substantially, reaching $1.43 \%$ of gross domestic product in 2008 (ref. 4), which is still much lower than in the United States or Japan (around $3 \%$ ), but is comparable to China (roughly $1.5 \%)$ and approaches the European average (1.9\%). Moreover, new research centres have been created and existing ones expanded, while the number of academics and students have increased substantially, in an attempt to reach the necessary critical mass for research in the future.

Efforts to boost the level of scientific productivity have been made particularly in research areas where the country already has a strong tradition. An example is the creation of a new bioethanol institute, a field in which Brazil has been a leader for a long time, particularly since the use of flex-fuel cars was made mandatory after the oil crises of 1973. The use of biofuels is still controversial, as many criticize its effects on biodiversity and on deforestation, and the

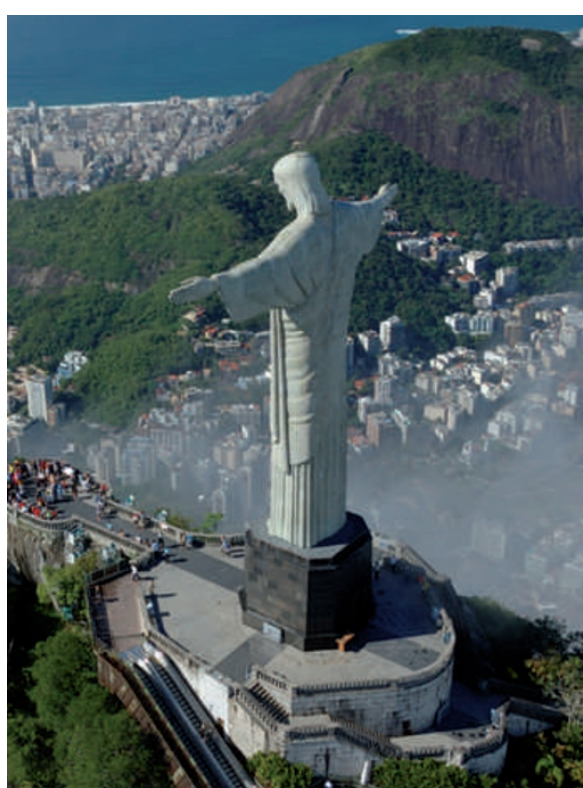

productivity in terms of papers published and overall citation numbers has increased substantially in the past few decades, the impact of the results is still well below that of the United States or Western European countries. According to a recent report by Thomson Reuters, the average citation in all fields of research between 1998 and 2008 was 5.58, while it was over 14 for the United States, more than 12 for England, over 11 for Germany and more than 10 each for Italy and France 5 .

Clearly it is mainly a question of time. Research in Brazil is after all just a few decades old. Not too long ago many university departments did not have any means to do research at all, and it was only very recently that the necessary infrastructure was implemented. What is undeniable is the awareness of the need to improve, especially in terms of visibility of the results. For example, the National Council of Technological and Scientific Development has introduced a programme of productivity fellowships, which affect both salaries and research funds of individual researchers ${ }^{6}$. The positive aspect of this project is that the fellowships are granted not only on the basis of number of publications and citations, but attention is also given to the specific contributions that a researcher has provided to a piece of work. Emphasis is also put on educational aspects, taking into account for example the number of $\mathrm{PhD}$ students supervised.

Lula's government will reach the end of its mandate at the end of 2010, and it is probably too early to envisage what the new candidates for the presidency will propose for science. But it is hard to imagine that the achievements made so far will be undone, whoever the new leader will be. Lula has even signed a series of bills to safeguard the future of the investments made by his government $^{7}$. The years to come promise to bring interesting developments, and we are eager to learn what these will be.

\footnotetext{
References

1. http://go.nature.com/G5CTto

2. Nature Mater. 9, 532-533 (2010).

3. Jorio, A., Sá Barreto, F. C., Sampaio, J. F. \& Chacham, H. Nature Mater. 9, 528-531 (2010).

4. http://go.nature.com/oTrB5N

5. http://sciencewatch.com/dr/cou/2008/08decALL/

6. http://www.cnpq.br/normas/rn_06_016_anexol.htm

. Nature 465, 674-675 (2010).
} 